\title{
EFFECT OF CERTAIN MICRONUTRIENTS ON SOME AGRONOMIC CHARACTERS, CHEMICAL CONSTITUENTS AND ALTERNARIA LEAF SPOT DISEASE OF FABA BEAN Abd El-Razek, U. A. ${ }^{1}$; Elham A. Dorgham ${ }^{2}$ and S. M. Morsy ${ }^{3}$ 1)Agron. Dept., Fac.Agric., Tanta Univ., Egypt. \\ 2) Agron. Dept., Nuclers Rec. Centre, Egypt. \\ 3) Plant Pathol. Res. Inst., Agric. Rec. Center, Giza, Egypt.
}

\section{ABSTRACT}

To study the effects of foliar application with micronutrients on yield and yield components of faba bean (c.v. Misr 1), an experimental research was conducted in complete randomized block design by three replications during the two growing seasons of 2009/2010 and 2010/2011 in Etay El-Baroud Agricultural Research Station, El-Behera Governorate. Results shwoed that, spraying with $\mathrm{Fe}+\mathrm{Zn}+\mathrm{Mn}$ increased plant height, number of pods/plant, number of seeds/pod, number of seeds/plant, 100 seed weight and seed yield /faddan in the combined data.

Also, chemical constituent, chlorophyll A, chlorophyll B, reducing sugars and the non reducing sugars significantly increased in all treatments spray with micronutrients compared with non-treated (control).

Meanwhile, Altermaria leaf spot incidence on treated plants significantly decreased $18.2 \%$ - $60.5 \%$ compared with non-treated control plants.

\section{INTRODUCTION}

Faba bean (Vicia faba L.) is generally regarded as an important source of plant proteins that could help in supplementing the meager amount of animal proteins in the diet of averaged Egyptians. The total area planted for production of dry beans was 336,000 Fad. producing 428,000 t during 1995-1999 Abd El-Salam, (2002). Deficiency of micronutrients, especially Zn, $\mathrm{Fe}$ and $\mathrm{Mn}$ are widespread in most crops in Egypt either due to low available concentration in the soil, high demand of crops, nutrient imbalance or unfavorable agronomic practices (Amberger, 1980; Wallace, 1980; El-Fouly, 1983; El-Fouly et al., 1984; Fawzi et al., 1987). Spraying of micronutrients under field conditions in Egypt was found to increase the yield (Eweida et al., 1980; El- Sheikh, 1981; Fawzi et al., 1983; Abdel Hadi et al., 1985; El-Fouly and Rezk, 1986 ; Gomma et al., 1986).

Chlorophyll content can be taken as an index of the extent of reduction in effective green area, so it is obvious that the disease reduces the photosynthetic activity in leaves and ultimately lead to lower yield ( Sinha et al . 1970 ).In this respect Rahhal (1993) found that Zn 4gm treatment showed the highest concentrations of chlorophyll (a) content of leaves. Meanwhile $\mathrm{Zn}$ $(8 \mathrm{gm}), \mathrm{Mn}(8 \mathrm{gm})$ and $\mathrm{Fe}(4 \mathrm{gm})$ treatments showed the highest concentrations of chlorophyll (b) content of leaves, $0.62,060$, and $0.57 \mathrm{mg} / \mathrm{g}$ leaves, respectively, while $\mathrm{Zn}(8 \mathrm{gm}), \mathrm{Mn}(8 \mathrm{gm}), \mathrm{Zn}(4 \mathrm{gm})$ and $\mathrm{Fe}(4$ and $8 \mathrm{gm}$ ) treatments showed the highest concentrations of the total chlorophyll content of leaves , 1.50 . 1.45, $1.39,1.37$ and $1.37 \mathrm{mg} / \mathrm{g}$ leaves , 
Abd El-Razek, U. A. et al.

respectively. Also, amount of charbohydrates in leaves and stem significant increased in all teratments compared with control. El-Shahaby and Mohamed (1983) found that all treatments of fungicides on onion plants due to significant increase of amount reducing and non reducing sugars further more, total sugars increased except when cuprosan was sprayed at $3 \mathrm{~g} / \mathrm{L}$ water.

On the other hand Alternaria leaf spot disease caused by Alternaria alternata are caused problem of bean plants during growing seasons (Honda et al . , 2001) There is a growing need to develop alternative approaches for controlling plant diseases. Induced resistance due to foliar application with micronutrants in some plants against plant diseases was reported by (Abd-Elkarem 2004, and El-Gamal et al., 2007) micronutrients which can be applied successfully in many area of plant production as a plant growth stimulant ( Scheuerll and Mahafee 2006 ).

The present study therefore was conducted to investigate potantioal of certain micronutrients to control Alternarial leaf spot and to enhance yield and quality of faba bean.

\section{MATERIAL AND METHODS}

Two field experiments were carried out at Etay El-Baroud Agricultural Research Station, El-Behera Governorate during 2009/2010 and 2010/2011 seasons to study the effect of $\mathrm{Fe}, \mathrm{Zn}, \mathrm{Mn}$ and their combination on the yield of faba bean C.V (Misr 1)

\section{A- Field studies:}

The field experiments were laid out in complete randomized block design included ninth treatments as the follows:-

1. Spraying plants with tap-water(Control)

2. with $(\mathrm{Fe})$ at $4 \mathrm{~g} / \mathrm{L}$

3. with $(\mathrm{Zn})$ at $4 \mathrm{~g} / \mathrm{L}$

4. with $(\mathrm{Mn})$ at $4 \mathrm{~g} / \mathrm{L}$

5. with $(\mathrm{Fe}+\mathrm{Mn})$ at $4 \mathrm{~g} / \mathrm{L}$

6. with $(\mathrm{Fe}+\mathrm{Zn})$ at $4 \mathrm{~g} / \mathrm{L}$

7. with $(Z n+M n)$ at $4 \mathrm{~g} / \mathrm{L}$

8. with $(\mathrm{Fe}+\mathrm{Zn}+\mathrm{Mn})$ at $4 \mathrm{~g} / \mathrm{L}$

9. with (Diathen M 45) at $250 \mathrm{~g} / \mathrm{L}$

Treatments applied twice, the first at 45 days after sowing, followed by the second at 15 days later.

Commercial Fe 12.5\%, Mn 12.5 and $\mathrm{Zn} \mathrm{12.5 \%} \mathrm{were} \mathrm{used} \mathrm{in} \mathrm{the}$ experiments. Micronutrients were spray at $4 \mathrm{gm} / \mathrm{L}$. water and Dithen $\mathrm{M}-45$ was used at rate of $250 \mathrm{~g} / 100 \mathrm{~L}$. water after 45 days of sowing. However, other agricultural practices were performed as commonly followed in the district. Alternaria leaf spot severity was recorded 7 days after last spray (75 days of sowing). 
The tested growth characteristics:

At harvest time (75 days of sowing), ten guarded plants were taken from each plot to investigate the following characters.

1- Plant height $(\mathrm{cm})$.

2- Number of branches/plant.

3- Number of pods/plant.

4- Number of seeds/plant.

5- Number of seeds per pod.

6- 100 - seed weight (g).

7- Seed yield/faddan (ton).

whole plants in each plot were harvested and left for air drying, then they we re threshed and the seeds (which were at $12 \%$ moisture) were weighted $(\mathrm{kg})$.

Determination of Leaf chlorophyll: Leaf chlorophyll content was determined spectrophotometer at $645 \mathrm{~nm}$ and $663 \mathrm{~nm}$ wavelengths) according to Grodzinsky and Grodzinsky (1973).

Chlorophyll (a) and (b) concentrations in $\mathrm{mg} / \mathrm{g}$ leaves after 70 days of sowing were calculated as follows:

Chl. $\mathrm{a}=[(12.7 \times$ O.D. 663$)-(2.69 \times$ O.D. 645$)] \times 0.1$

Chl. $b=[(22.9 \times$ O.D. 645$)-(4.68 \times$ O.D. 663$)] \times 0.1$

Total chlorophyll $=\mathrm{Chl}$. a $(\mathrm{mg} / \mathrm{g}$ fresh weight of leaves $)+\mathrm{Chl} . \mathrm{b}$ (mg/g fresh weight of leaves).

These equations were adapted to optical density measurements of acetone- water extracts of the chlorophyll in a $1 \mathrm{~cm}$ vial.

\section{Determination of soluble sugars:}

Each sample of faba bean leaves was cut of small pieces and $5 \mathrm{gm}$ was taken and transferred to beaker of $500 \mathrm{cc}$, in which $400 \mathrm{ml}$ of distilled water and $3 \mathrm{mg}$ of calcium carbonate were added, and the mixture was boiled for 30 minutes. After cooling, the mixture was filtered with filter paper Watman No.2. the clarification occurred by adding lead acetate $10 \%$ and swirled till appearance of the precipitate. After filtration, potassium oxalate was added to the filtrate to precipitate the extra amounts of lead acetate. The resulting filtrate was transferred into volumetric flask of $500 \mathrm{cc}$ and completed to the mark. to prepare a blank, $400 \mathrm{ml}$ of distilled water with $3 \mathrm{gm}$ calcium carbonate were placed in a beaker and the mixture was boiled for 30 minutes and filtered. The extracts were kept in a refrigerator until the determination of total, reducing and non- reducing sugars in each sample of extract.

Total soluble sugars:

The soluble sugars were estemated calorimetrically according to Dubois et al.(1956).

The sugar content was calculated as glucose from a standard curve prepared for it. Determinations of total, reducing and non-reducing sugars were calculated as milligrams of glucose per $100 \mathrm{~g}$ fresh weight.

Disease assessments of Alternaria leaf spot:

Average disease severity of Alternaria leaf spot occurred naturally on faba bean in the field recorded according to Vakalunkis (1990).

Disease scale from 0 to 4 for the leaf area infected was used as follows :

- $\quad 0=$ No leaf lesions.

- $1=25 \%$ or less.

- $\quad 2=26 \%$ to 50 
Abd El-Razek, U. A. et al.

- $3=51 \%$ to 75 .

- $\quad 4=76 \%$ to $100 \%$ infected leaf area.

The formula adopted by Hanounik (1986) as follow:

Disease severity (D.S)\% $=\frac{E(\text { NPCKCR })}{\text { NIP MNSC }} \times 100$

Where :

NPC $=$ No. of plants in each class rate.

$\mathrm{CR}=$ Class rate.

NIP $=$ No. of infected plants.

MSC = Maximum severity class rate.

Isolation and dentification

Under field condation were growing faba bean plants, when observet of symptom disease of Altermaria leaf spot at natural infected takeing leaves and isolate fungal on P D A media in vitro. Fungal were kept in selant until identification in Agricultural Research Centre, Giza , Egypt .

\section{Statistical analysis}

All data were statistically analyzed according to the technique of analysis of variance (ANOVA) for the complete randomized block design in two seasons and then the combined analysis was achieved by Gomez and Gomez (1984) using means of "MSTAT-C" computer software package. Least Significant Difference (LSD) method was used to test the differences between treatment means at $5 \%$ level of probability as described by Snedecor and Cochran (1980).

\section{RESULTS AND DISCUSSION}

\section{1-Effect of micronutrients on growth characters:}

Data presented in Table (1) showed that, foliar apllications with $\mathrm{Fe}$, $\mathrm{Zn}$ and $\mathrm{Mn}$ alone or in comnination of them significantly increased all growth characters.

The highest plant height $(99.93 \mathrm{~cm})$ was obtained with sparying $\mathrm{Fe}+\mathrm{Zn}$ followed by $\mathrm{Fe}+\mathrm{Zn}+\mathrm{Mn}(94.27 \mathrm{~cm})$ and $\mathrm{Fe}+\mathrm{Mn}(91.77 \mathrm{~cm})$, while the lowest plant height $(82.20 \mathrm{~cm}$ ) was recorded with sparying water (untreated control). This was in agreement with Bozorgi et al., (2011) who reported that, the highest plant height was obtained with foliar zinc spraying. The highest number of branches/plant was obtained with sparying $\mathrm{Fe}+\mathrm{Zn}$. While, the other treatments were not significantly different from the untreated control for the number of branches per plant. The lowest values of number of branches/plant (2.63 branch / plant) recorded with spraying Fe $+Z n+M n$, only $\mathrm{Mn}$ and control which there were no significant differences between them. 
Table (1): Effect of foliar application with Fe, $\mathrm{Zn}$ and Mn on growth, yield and yield components of faba bean plants in the combined data

\begin{tabular}{|l|c|c|c|c|c|c|c|}
\hline Treatments & $\begin{array}{c}\text { Plant } \\
\text { height } \\
\mathbf{( c m )}\end{array}$ & $\begin{array}{c}\text { No. of } \\
\text { branches/ } \\
\text { plant }\end{array}$ & $\begin{array}{c}\text { No. of } \\
\text { pods/plant }\end{array}$ & $\begin{array}{c}\text { No. of } \\
\text { seeds/pod }\end{array}$ & $\begin{array}{c}\text { No. of } \\
\text { seeds/plant }\end{array}$ & $\begin{array}{c}\text { Seed } \\
\text { seed } \\
\text { weight } \\
\text { (g) }\end{array}$ & $\begin{array}{c}\text { yield/ } \\
\text { faddan } \\
\text { (ton) }\end{array}$ \\
\hline Fe & $85.83 \mathrm{bc}$ & $3.00 a b$ & $8.67 a b$ & $3.27 a b$ & $30.38 a b$ & $88.91 a b$ & $2.75 a b$ \\
\hline $\mathbf{F e + Z n}$ & $99.93 a$ & $3.23 a$ & $11.07 a$ & $3.56 a b$ & $37.96 a b$ & $93.75 a$ & $3.60 a b$ \\
\hline $\mathbf{F e + M n}$ & $91.77 a b c$ & $2.70 a b$ & $9.67 a$ & $3.70 a b$ & $35.28 a b$ & $89.97 a b$ & $3.19 a b$ \\
\hline $\mathbf{F e + Z n + M n}$ & $94.27 a b$ & $2.67 b$ & $10.00 a$ & $4.02 a$ & $40.33 a$ & $89.75 a b$ & $3.66 a$ \\
\hline $\mathbf{Z n}$ & $88.57 \mathrm{bc}$ & $2.70 a b$ & $6.20 b$ & $3.57 a b$ & $28.76 a b$ & $87.34 a b$ & $3.11 a b$ \\
\hline $\mathbf{M n + Z n}$ & $85.37 \mathrm{bc}$ & $2.90 a b$ & $9.87 a$ & $3.06 b$ & $35.82 a b$ & $87.64 a b$ & $2.84 a b$ \\
\hline $\mathbf{M n}$ & $89.47 \mathrm{bc}$ & $2.63 b$ & $9.93 a$ & $3.68 a b$ & $32.38 a b$ & $87.92 a b$ & $2.93 a b$ \\
\hline Diathane 45 & $90.43 a b c$ & $2.70 a b$ & $10.87 a$ & $3.99 a$ & $34.66 a b$ & $89.27 a b$ & $2.63 a b$ \\
\hline control & $82.20 \mathrm{c}$ & $2.63 b$ & $6.13 b$ & $3.33 a b$ & $25.21 b$ & $85.86 b$ & $2.49 b$ \\
\hline LSD 0.05 & 7.35 & 0.56 & 2.20 & 0.86 & 10.03 & 4.74 & 0.82 \\
\hline
\end{tabular}

\section{2-Effect of micronutrients on yield and yield components:}

Table(1) showed that, all treatments (except for $\mathrm{Fe}$ alone and $\mathrm{Zn}$ alone) significantly increased the number of pods/plant. Spraying with $\mathrm{Fe}$ or Zinc did not exhibit a significant effect compared to control in the combined data. This was generally in agreement with El-Gizawy and Mehasen (2009), El-Fouly et al (2010), El-Masri et al., (2002), Rashed and Ahmed (1997), Rizk and Abdo (2001) and Bozorgi et al., (2011) as they reported that, the lowest pods per plant were found without spraying zinc. On the other hand, Ewieda et al., 1980; Saber 1980; El-Sheikh, 1981; Abdel Aziz et al., 1982. Fawzi et al., 1983; El-Fouly and Rezk, 1986; Gomaa et al, 1986; Ibrahim and El-Labban, 1986; Amin et al, 1988; El-Masri et al., (2002) they found that, two sprays of zinc without Fe resulted in the highest number of pods per plant, either spating Fe decreased number of pods per plant.

Concerning the number of seeds/pod the different treatments did not exhibit a significant effect in this respect compared to the control. However El-Masri et al., (2002) found that, spraying with zinc increased number of seeds/plant. Genotypic differences for the character were also recorded by Abdalla et al., (2000), whereas Ashmawy et al., (1998) found insignificant differences for this character.

Also, Table (1) showed significant effect on number of seeds per plant. The highest values were recorded with sparying $\mathrm{Fe}+Z n+M n$, while, the other treatments were not significantly different from the control.

It is clear from the data given in Table (1) that, spraying with $\mathrm{Fe}+\mathrm{Zn}$ recorded the highly significant value of 100 seed weight compered with the control. This was in harmony with Bozorgi (2011) who found that, the highest 100 seed weight was obtained with $1 \mathrm{~g} / \mathrm{L}$ foliar zinc spaying. However, Yassen et al., (2010) found that, the highest increment (16\%) was obtained when plants sprayed with micronutrients mixture $(\mathrm{Fe}+\mathrm{Zn}+\mathrm{Mn})$ as compared with control treatment.

Also, it is evident from Table (1) data that Spraying with $\mathrm{Fe}+\mathrm{Zn}+\mathrm{Mn}$ showed the highest values of seeds yield/faddan in the combined data, while the lowest value recorded with spraying Zinc. Allam et al., (2004), reported 
Abd El-Razek, U. A. et al.

that, the foliar spray with the combination of (Fe:Mn:Zn) showed a highly significant increase in broad bean seed yield. Similar results were confirmed by other Monged et al., (1988), Baza et al., (1992), Monged et al., (1994) and Sabik et al., (2001). On the other hand, Azarpour et al., (2011) and Bozorgi (2011) they found that, the lowest seed yield per plant found without use of zinc spraying.

Such need of broad bean, and other crops, to micronutriets in Egypt may be due to seceral reasons; the great nutritional need of the high productivity of the crops, the discontinuity of the precipitation of the Nile mud, the intensive cropping system used and high $\mathrm{pH}$ value of most Egyptian soils which hinders the utilization of most of micronutrients by plants (Hamissa and Abdel Salam, 1999)

\section{3- effect of micronutrients on sugar content:}

Results presented in Table (2) showed clearly that the lowest amount of reducing sugars in leaves and stem of faba bean plants being 3.1 and 1.2 $\mathrm{mg}$ per $\mathrm{g}$ fresh weight, respectively, when compared with $\mathrm{Fe}$, the highly amount reducing sugar content 3.9 and $2.0 \mathrm{mg}$, respectively. Also, $\mathrm{Zn}$ showed the lowest amount reduing sugars in leaves and stem 3.4 and 1.2 $\mathrm{mg}$, respectively. On the other hand, the other micronutrients gave intermediate amount in reducing sugars in leaves and stems. Leaves from all treatments with micro-elements contained higher amounts of reducing sugars than that in stem of the some treatments. There results are agreement With $\mathrm{El}$ - shahaby and Mohamed ( 1983) as they found that the amount of reducing sugars decreased at the lower rates of fungicides but increased for the higher rates. On the other hand, amount of non-reducing sugars increased for all treatments. Furthers more, total sugars increased in all treatments except when Cuprosan was sprayed at $3 \mathrm{~g} / \mathrm{L}$ water .

Table (2): Sugar contents $(\mathrm{mg} / \mathrm{g}$ fresh weight in leaves and stem of faba bean treated with chealte micro-elements 75 days after sowing

\begin{tabular}{|l|c|c|c|c|c|c|}
\hline \multirow{2}{*}{\multicolumn{2}{c|}{ Treatments }} & \multicolumn{5}{c|}{ Sugar contents mg/1g fresh weight } \\
\cline { 2 - 7 } & \multicolumn{4}{c|}{ Leaves } & \multicolumn{3}{c|}{ Stem } \\
\cline { 2 - 7 } & Reducing & $\begin{array}{c}\text { Non- } \\
\text { reducing }\end{array}$ & $\begin{array}{c}\text { Total } \\
\text { sugars }\end{array}$ & Reducing & $\begin{array}{c}\text { Non- } \\
\text { reducing }\end{array}$ & $\begin{array}{c}\text { Total } \\
\text { sugars }\end{array}$ \\
\cline { 2 - 7 } & 3.9 & 4.8 & 8.7 & 2.0 & 3.9 & 5.9 \\
$\mathrm{Fe}+\mathrm{Zn}$ & 3.6 & 4.8 & 8.4 & 1.8 & 2.8 & 4.6 \\
$\mathrm{Fe}+\mathrm{Mn}$ & 3.7 & 4.6 & 8.3 & 1.7 & 3.5 & 5.2 \\
$\mathrm{Fe}+\mathrm{Mn}+\mathrm{Zn}$ & 3.8 & 4.8 & 8.6 & 1.3 & 2.1 & 3.4 \\
$\mathrm{Zn}$ & 3.4 & 3.6 & 7.0 & 1.2 & 2.0 & 3.2 \\
$\mathrm{Zn}+\mathrm{Mn}$ & 3.7 & 4.3 & 8.0 & 1.9 & 2.1 & 4.0 \\
$\mathrm{Mn}$ & 3.5 & 3.9 & 7.5 & 1.3 & 2.0 & 3.3 \\
Diathiane M45 & 3.1 & 3.3 & 6.4 & 1.9 & 1.6 & 3.5 \\
Control & 3.3 & 3.9 & 7.2 & 1.3 & 2.0 & 3.3 \\
(non - treated ) & & & & & & 0.38 \\
\hline L.S. D at 0.05\% & 0.3 & 0.2 & 0.8 & 0.34 & 0.38 & 0.91 \\
\hline
\end{tabular}

Data are average of three replicates.

\section{4- Effect of micronutrients on the chlorophyll content of leaves:}

The results recorded in Table(3) showed that micronutrients application at rate of $4 \mathrm{~g} / \mathrm{L}$. increased significantly chlorophyll A from 0.84 
$\mathrm{mg} / \mathrm{g}$ leaves treated with micronutrients compared with control $0.6 \mathrm{mg} / \mathrm{g}$ leaves).

The same trend was found in chlorophyll $b$ content, but values were significantly lower than that of chlorophyll $A$. On the other hand, total chlorophyll increased significantly by the micronutrients and Diathane- M45 treatments. The most pronounced increase was found in the leaves of plants treated with Fe combined with $\mathrm{Mn}$ ( $1.97 \mathrm{mg} / \mathrm{g}$ fresh weight).

Table (3): Effect of some chelated micronutrients as foliar application on the chlorophyll a, b and the total chlorophyll content ( $\mathrm{mg}$ / g f.w. leaves ).

\begin{tabular}{|l|c|c|c|}
\hline \multicolumn{1}{|c|}{ Elements } & Chlorophyll(a) & Chlorophyll (b) & Total chlorophyll \\
\hline $\mathrm{Fe}$ & $0.70 \mathrm{~d}$ & $0.44 \mathrm{~d}$ & 1.14 \\
$\mathrm{Zn}$ & $0.81 \mathrm{~b}$ & $0.52 \mathrm{a}$ & 1.33 \\
$\mathrm{Mn}$ & $0.74 \mathrm{c}$ & $0.42 \mathrm{e}$ & 1.16 \\
$\mathrm{Fe}+\mathrm{Zn}$ & $0.66 \mathrm{e}$ & $0.39 \mathrm{f}$ & 1.05 \\
$\mathrm{Fe}+\mathrm{Mn}$ & $0.82 \mathrm{~b}$ & $0.48 \mathrm{~b}$ & 1.97 \\
$\mathrm{Zn}+\mathrm{Mn}$ & $0.64 \mathrm{f}$ & $0.42 \mathrm{e}$ & 1.06 \\
$\mathrm{Fe}+\mathrm{Mn}+\mathrm{Zn}$ & $0.84 \mathrm{a}$ & $0.41 \mathrm{e}$ & 1.25 \\
Diathane- M45 & $0.73 \mathrm{c}$ & $0.46 \mathrm{c}$ & 1.19 \\
Cheak (non- treated ) & $0.61 \mathrm{~g}$ & $0.36 \mathrm{~g}$ & 0.97 \\
\hline L.S . D at 0.05 & 0.017 & 0.17 & 0.29 \\
\hline
\end{tabular}

${ }^{*}$ Data are avereg of three replicates .

These results indicated that spraying micronutrients ( $\mathrm{Fe}$ and $\mathrm{Mn}$ ) stimulated the activity of chloroplasts this was followed by $\mathrm{Zn}(1.33 \mathrm{mg} / \mathrm{g}$ fresh weight leaves ) while the lowest was found with $\mathrm{Fe}_{+} \mathrm{Zn}(1.05 \mathrm{mg} / \mathrm{gm}$ fresh weight of leaves). These results are agreements with those of Rahhal (1993) who found that the total chlorophyll content of broad bean leaves showed the highest concentrations with $\mathrm{Zn}(8 \mathrm{gm}), \mathrm{Mn}(8 \mathrm{gm})$ and $\mathrm{Zn}(4 \mathrm{gm})$ treatments. 5-Effect of micronutrients on Alternaria leaf spot in feba bean plant:

Results in Table (4) and Fig. (1) indicated that most treatments significantly decreased the Alternaria leaf spot severity of faba bean plants during the two successive seasons. The most effective treatments was $\mathrm{Mn}$ at rate of $4 \mathrm{~g} / \mathrm{L}$ water which reduced the disease incidence by $51.3 \%$ during season 2010 while reduced disease incidence by $60.5 \%$ during season 2011 in combination with $\mathrm{Zn}$, followed by (58.2\%) with $\mathrm{Fe}+\mathrm{Zn}+\mathrm{Mn}$ when spray as a combination in same season .

Also, Alternaria leaf spot was more severe at the lower parts of the plant. This results are agreement Abd El-hai et al. (2009) who found that seed soaking method or foliar spray of micronutrients ( $\mathrm{Mn}$ and $\mathrm{Z}$ at $2 \mathrm{~g} \mathrm{~L}^{-1}$ ) were tested to control of damping- off and charcoal rot diseases of sunflower ( varieties Sakha53 and Giza 102 ). All treatments of antioxidante and microelement significantly reduced the incidence of charcoal rot disease .

Also, the correlation co-efficient between total sugar and disease severity\% in leaves was positive and was 0.319 and 0.289 , during the first and second year, respectively. 
Abd El-Razek, U. A. et al.

Table (4): Alternaria leaf spot in faba bean plants as affected by foliar application with micronutrients under field condition

\begin{tabular}{|c|c|c|c|c|c|c|c|c|c|c|c|c|c|c|c|c|}
\hline \multirow{3}{*}{ Treatment } & \multicolumn{7}{|c|}{ First season 2010} & \multirow{3}{*}{ Mean } & \multicolumn{7}{|c|}{ Second season 2011} & \multirow{3}{*}{ Mean } \\
\hline & \multicolumn{3}{|c|}{$\begin{array}{c}\text { Disease } \\
\text { severity\% }\end{array}$} & \multirow{2}{*}{ Mean } & \multicolumn{3}{|c|}{ Reduction \% } & & \multicolumn{3}{|c|}{$\begin{array}{c}\text { Disease } \\
\text { severity\% }\end{array}$} & \multirow{2}{*}{ Mean } & \multicolumn{3}{|c|}{ Reduction \% } & \\
\hline & $\begin{array}{l}20 \\
\mathrm{~cm}\end{array}$ & $\begin{array}{l}40 \\
\mathrm{~cm}\end{array}$ & $\begin{array}{l}60 \\
\mathrm{~cm}\end{array}$ & & \begin{tabular}{|l|}
20 \\
$\mathrm{~cm}$
\end{tabular} & $\begin{array}{l}40 \\
\mathrm{~cm}\end{array}$ & $\begin{array}{l}60 \\
\mathrm{~cm}\end{array}$ & & \begin{tabular}{|l|}
20 \\
$\mathrm{~cm}$
\end{tabular} & $\begin{array}{l}40 \\
\mathrm{~cm}\end{array}$ & $\begin{array}{l}60 \\
\mathrm{~cm}\end{array}$ & & $\begin{array}{l}20 \\
\mathrm{~cm}\end{array}$ & $\begin{array}{l}40 \\
\mathrm{~cm}\end{array}$ & $\begin{array}{l}60 \\
\mathrm{~cm} \\
\end{array}$ & \\
\hline $\mathrm{Fe}$ & 36.7 & 28.3 & 10.0 & 25.3 & 10.6 & 10.7 & 33.3 & 18.2 & 21.7 & 15.0 & 5.0 & 13.9 & 23.3 & 17.0 & 50.0 & 30.4 \\
\hline $\mathrm{Fe}+\mathrm{Zn}$ & 28.3 & 20.0 & 6.7 & 18.3 & 23.1 & 36.9 & 55.3 & 41.4 & 20.0 & 13.3 & 5.0 & 12.7 & 29.3 & 27.3 & 50.0 & 35.5 \\
\hline $\mathrm{Fe}+\mathrm{Mn}$ & 25.0 & 18.3 & 6.7 & 16.7 & 40.0 & 42.3 & 55.3 & 45.9 & 16.7 & 11.7 & 6.7 & 11.7 & 41.0 & 36.1 & 33.0 & 36.7 \\
\hline $\mathrm{Fe}+\mathrm{Zn}+\mathrm{Mn}$ & 20.0 & 15.0 & 8.3 & 14.4 & 52.0 & 52.7 & 44.7 & 49.8 & 13.3 & 8.3 & 3.3 & 8.3 & 53.0 & 54.6 & 67.0 & 58.2 \\
\hline $\mathbf{Z n}$ & 26.7 & 23.3 & 6.7 & 18.9 & 36.0 & 26.5 & 55.3 & 39.3 & 16.7 & 11.7 & 5.0 & 11.1 & 41.0 & 36.1 & 50.0 & 42.4 \\
\hline$Z n+M n$ & 25.0 & 21.7 & 10.0 & 18.9 & 40.0 & 31.5 & 33.3 & 34.9 & 13.3 & 10.0 & 1.7 & 8.3 & 53.0 & 45.6 & 83.0 & 60.5 \\
\hline Mn & 25.0 & 16.7 & 5.0 & 15.6 & 40.0 & 47.3 & 66.7 & 51.3 & 18.3 & 8.3 & 3.3 & 10.0 & 35.3 & 54.6 & 67.0 & 52.4 \\
\hline \begin{tabular}{|l|} 
Diathane - \\
M45
\end{tabular} & 8.33 & 6.7 & 1.7 & 5.6 & 80.1 & 78.9 & 88.7 & 82.6 & 6.7 & 1.7 & 0.0 & 2.8 & 76.3 & 90.7 & $\mid 100$ & 89.0 \\
\hline $\begin{array}{l}\text { Check (un- } \\
\text { treated) }\end{array}$ & 41.7 & 31.7 & 15.0 & 29.5 & - & - & - & - & 28.3 & 18.3 & 10.0 & 18.9 & - & - & & - \\
\hline \begin{tabular}{|l|} 
L.S.D \\
0.05
\end{tabular} & 9.3 & 7.1 & n.s & 6.7 & & & & & 11.6 & 7.7 & n.s & 4.4 & - & - & & - \\
\hline
\end{tabular}

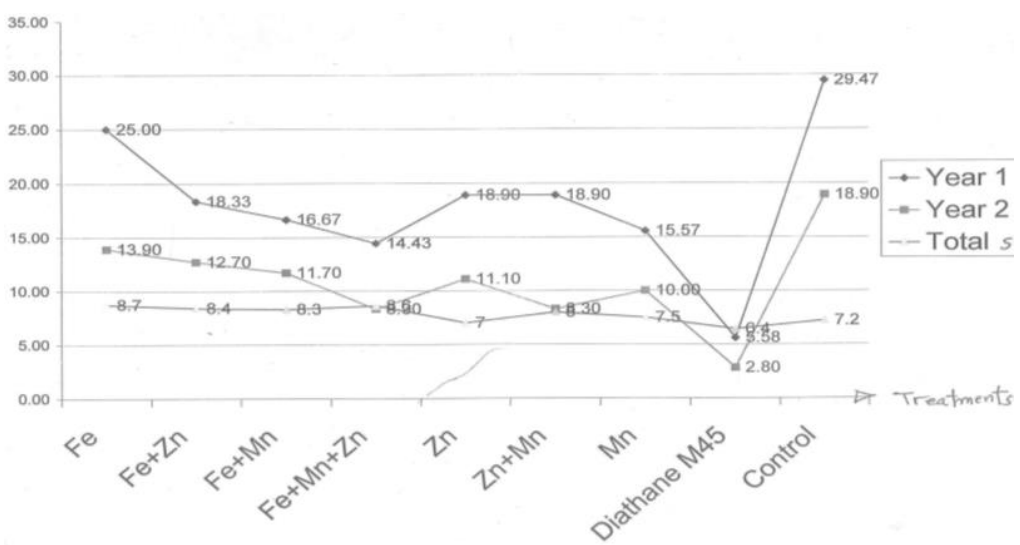

Fig. (1) : Relation between total sugar and disease severity in leaves of faba bean during two seasons 2010 and 2011

\section{CONCLUSION}

According to the obtained results from this study, it can be concluded that, spraying $\mathrm{Fe}, \mathrm{Zn}$ and $\mathrm{Mn}$ alone or in combination could be recomend to control leaf spots and to enhance yield and quality of faba bean under the enivronmental conditions of Etay El-Baroud Agricultural Research Station Farm, El-Behera Governorate. 


\section{REFERENCES}

Abdalla, M.M.F., D.S. Darwish, A.A.Ali and E.A.A.El-Emam, (2000). Investigation on faba bean (Vicia faba L.). Variability and clustering of faba bean Land Races. Egypt.L. Plant Breed. 4:257-272.

Abdel-Aziz, I.M.; M.H. Mohamed; M.A.A.Amin and I.A. Ibrahim, (1982). Effect of phosphorus and zinc application by different methods on broad bean plants (Vicia faba L.) in calcareous soil. Res. Bull. No.725.

Abdel Hadi, A.H., K.G. Asy, H.W. Doering, M.S. Kadr, A.A. Moustafa and M.E. Taha, (1985). Effect of foliar fertilization in different crops under Egyptian conditions. Proc. 1st Int. Symp. On Foliar Fertilization, pp: 126-141.

Abd El-Hai, K.M., M.A. El-Metwally S.M El-Baz and A.M. Seid (2009). The use of antioxidants and micronutrients for controlling damping-off caused by Rhizoctonia solani and charcoal rot caused by Macrophomina phosolina on sunflower plant, Pathal. J., 2009.

Abd-El-Kareem, F., (2007). Potassium or sodium bicarbonates in combination with Nerol for controlling early blight disease of potato plants under laboratory, greenhouse and field conditions. Egypt. J. of Phytopathol (In Press).

Abd-El-Karem, F., Nehal El-Mougy, S., Nadia El-Gamal, G. and Y.O. Fatouh , (2004). Induction of Resistance in Squash Plants Against Powdery Mildew and Alternaria Leaf Spot Diseases Using Chemical Inducers As Protective or Therapeutic Treatments. Egypt. J. Phytopathol., 32 (No., 1-2) : 65-76.

Abd El-Salam, M.E. (2002). Egyptian contemporary agriculture progress despite server constraints. Advances in Agricultural Research in Egypt., 4(1): 71-72

Allam, S.M.M., H.G. Abu El-Fotoh, A.A. Abd El-Magid and Nadia O.Monged, (2004). Some nutritional traits to increase broad bean yield and quality. Egypt.J.Appl.Sci.,19(9B): 736-750

Amberger, A., 1980. Foliar application of micronutrients uptake and incorporation into metabolism. Proc. 2nd Workshop on "Micronutrients and Plant Nutrition", Mariut- Egypt, pp. 47-60.

Amin, M.A.A.; M.S.M.Baza and F.H.El-Fendy, (1988). Effect of the number of sprays of some micronutrients on the growth, yield and mineral composition of broad bean plants. Ann.Agric. Sci. Moshtohor., 26:2007-2022.

Ashmawy, F., S.A.S. Mehasen and M.S.A. Mohamed, (1998). the relative contribution of some characters of seeds yield in some faba bean varieties grown under three population densities. Bull. Fac. Agric. Univ. Cairo, 49:517-532.

Azarpour, E.,M.K.Motamed, M. Moraditochaee and H. R. Bozorgi, (2011). Study effects of zinc spraying and nitrogen fertilizer on yield and yield components of Pinto Bean. World Applied Sciences Journal, 13(7):1697-1701. 
Baza, M.S.M., Nadia O.Monged and B.M. Hegazy, (1992). Some manurial trials to increase Faba bean yield by using some micronutrients. Egypt.J.Appl.Sci., 7(3):869-873.

Bozorgi, H.R.;E.Azarpour and M. Moradi, (2011). The effects of bio, mineral nitrogen fertilization and foliar zinc spraying on yield and yield components of Faba bean. World Apllied Sci. J., 13(6):1409-1414.

Dubois, M.; K.A. Gilles, J.K. Hamilton; P.A. Rebers and F. Smith (1956). Colorimetric method for determination of sugars and related substances. Anal. Chem., 28: 350-356.

El-Fouly, M.M., (1983). Micronutrients in arid and semi-arid areas: Levels in soil and plants and the need for fertilizers with reference to Egypt. Proc. 17th Coll. Int. Potash Institute, pp; 163-173. Rabat and Marrakech/ Morocco.

El-Fouly, M.M., A.F.A. Fawzy, A.H. Firgany and F.K. El-Baz, (1984). Micronutrient status of crops in selected areas in Egypt. Commun. Soil. Sci. PI. Annal., 15: 1 175-1 189.

El-Fouly, M.M. and A.I. Rezk, (1986). Micronutrient status of some food crops increasing yield through micronutrient foliar application in Beheira/Egypt. Proc. 1st Int. Symp. On Foliar Fertilization,.pp.153-166.

El-Fouly, M.M., Z.M. Mobarak and Z.A. Salama, (2010). Improving Tolerance of Faba Bean during Early Growth Stages to Salinity through Micronutrients Foliar Spray. Academic Press. Notulae Scientia Biologicae. 2(2): 98-102.

El-Gamal, Nadia, G. F. Abd-El-Kareem, Y.O. Fotouh and El-Mougy, Nehal S. (2007). Induction of systemic resistance in potato plants against late and early blight diseases using chemical inducers under greenhouse and field conditions. Research J. Agricultural and Biological Science, 3 (2) : 73-81

El-Gizawy, N.K.B. and S.A.S. Mehasen, (2009). Response of Faba Bean to Bio, Mineral Phosphorus Fertilizers and Foliar Application with Zinc. World Applied Sciences J., 6(10): 1359-1365.

EL-Masri, M.F., A. Amberger, M. Mohamed, El-Fouly and A.L. Rezk, (2002). $\mathrm{Zn}$ increased flowering and pod setting in faba beans and its interaction with $\mathrm{Fe}$ in relation to their contents in different plant parts. Pakistan I., Biological Sci., 5(2): 143-145.

El-Shehaby, A.I. and H.A. Mohamed (1985). Some side effects of fungicides on onion plants. Agric. Rese. Rev., 63, No.2. pp. 89 : 98.

El-Sheikh, M.H., (1981). Studies on faba bean. Effect of major cultural practices and micro elements on faba bean. M.Sc. Thesis, University of Alexandria, Egypt.

Eweida, M.H.T., A.M. Hagras and H.A. Saber, (1980). Effect of inoculation with Rhizobium sp., fertilizer treatments and zinc sulphate on yield and yield components of field bean. Research Bulletin, Faculty of Agric., Ain Shams University, No. 1383; 26 pp.

Fawzi, A.F.A., A. Amberger and M.M. El-Fouly, (1987). Nutrient status of field crops in the Valley area. Agrochem., 31: 534-547. 
Fawzi, A.F.A., A.H. Firgany, A.I.Rezk and M.A. Kishk, (1983). Response of Vicia faba bean to $\mathrm{K}$ and Micronutrient Fertilizers. Egyptian J. Bot., 26: 113-121.

Gomaa, M.A., H.A. Zied and F.I. El-Araby, (1986). The effect of spraying with some micronutrient elements on growth and yield of broad bean (Vicia faba L.). Ann. Agric. Sci. Moshtohor, 24: 658-666.

Gomez, K.N. and A.A. Gomez (1984). Statistical procedures for agricultural research. 2nd ed. John Wiley and Sons, New York.

Grodzinsky, A.M. and D.M. Grodzinsky (1973). Short reference in plant physiology. Naukova Domlka, Riev. R.U.R. pages, 433-34 (C.F. Thesis M. Sc. Ahmed. W.S., 1988. Univ. Alex.).

Hamissa, M.R. and Abdel Salam, (1999). Fertilizer management for cotton in Egypt.Adv.Agric. Res. In Egypt. 1, (2):53-113

Hanounik, S.B. (1986). Screening Techniques for Disease Resistance in Faba Bean. International Center for Agricultural Research in the Dry Areas (ICARDA), Aleppo, Syrig, pp: 59.

Honda, Y., M.Z. Rahman, S.Z. Islam and N. Muroguchi, (2001). Leaf Spot Disease of Broad Bean Caused by Alternaria tenuissima Japan Plant Dis., 85 : 95-96.

Ibrahim, A.A. and T.T. El-Labban, (1986). Effect of kinetin, cycocel and some micronutrients on the accumulation of some micronutrients in Vicia faba. Ann. Agric. Sci. Moshtohor, 24 : 317-328.

Monged, Nadia, O., A.H.A.Hussin, H.M. Farag and M.A. El-Boria, (1988). Effect of micronutrients application on faba bean yield in Minia,Fayoum and Behara Governorates. Nineth Annual Cordination Meeting.

Monged, Nadia, O. and M.S.M. Baza,(1994). Effect of NPK and some micronutrients of faba bean. Egypt.J.Appl.Sci., 9(3):1-10.

Rahhal, M.M.H. (1993). Effect of Micronutrients on some fungal diseases of broad bean. Alex. Sci. Exch., 14. (1) pp. 97-113.

Rashed, M.H. and H.A. Ahmed, (1997). Physiological studied on the effect of iron and zinc supplied on faba bean plant. I. Agric. Sci. Mansoura Univ., 22(3): 729-743.

Rizk, W.M. and F.A. Abdo, (2001). The response of two mung bean cultivars to zinc, manganese and boron II. Yield and chemical composition of seeds. Bull. Fac. of Agnc. Cairo Univ., 52(3): 467-477.

Saber, H.A., (1980). Study on the effect of some cultural treatments on yield quality in field bean. M. Sc. Thesis, University of Al-Azhar, Egypt.

Sabik, F.A.,M.S.M.Baza and Nadia O. Monged, (2001). Effect of biofertilizers and micronutrients application with different methods on faba bean. Egypt. J.Appl.Sci., 16(10):80-93.

Scheuerell, S.J. and W.H. Mahaffee, (2006). Variability Associated with Suppression of Gray Mold (Botrytis cinerea) on Geranium by Foliar Applications of Nanaerated and Aerated Compost Teas. Plant Dis., 90 : 1201-1208.

Snedecor, G.W. and W.G. Cocharan, (1967). Statistical Methods. 6th ed. lowa State University press.

Vakalunakis, D.J., (1990). Host range of Alternaria alternate f.sp. cucurbitae causing leaf spot of cucumber. Plant Dis., 84: 27-30. 
Abd El-Razek, U. A. et al.

Wallace, A., (1980). Some present and potential micronutrient problems of sandy desert soils of the Near East. Proc. 2nd Workshop on " Micronutrients and Plant Nutrition Problems in Egypt ". pp: 55-88

Yassen, A., E.A.A., Abou El-Nour and S.Shedeed, (2010). Response of wheat to foliar spary with urea and micronutrients. Journal of American Science, 6(9):14-22.

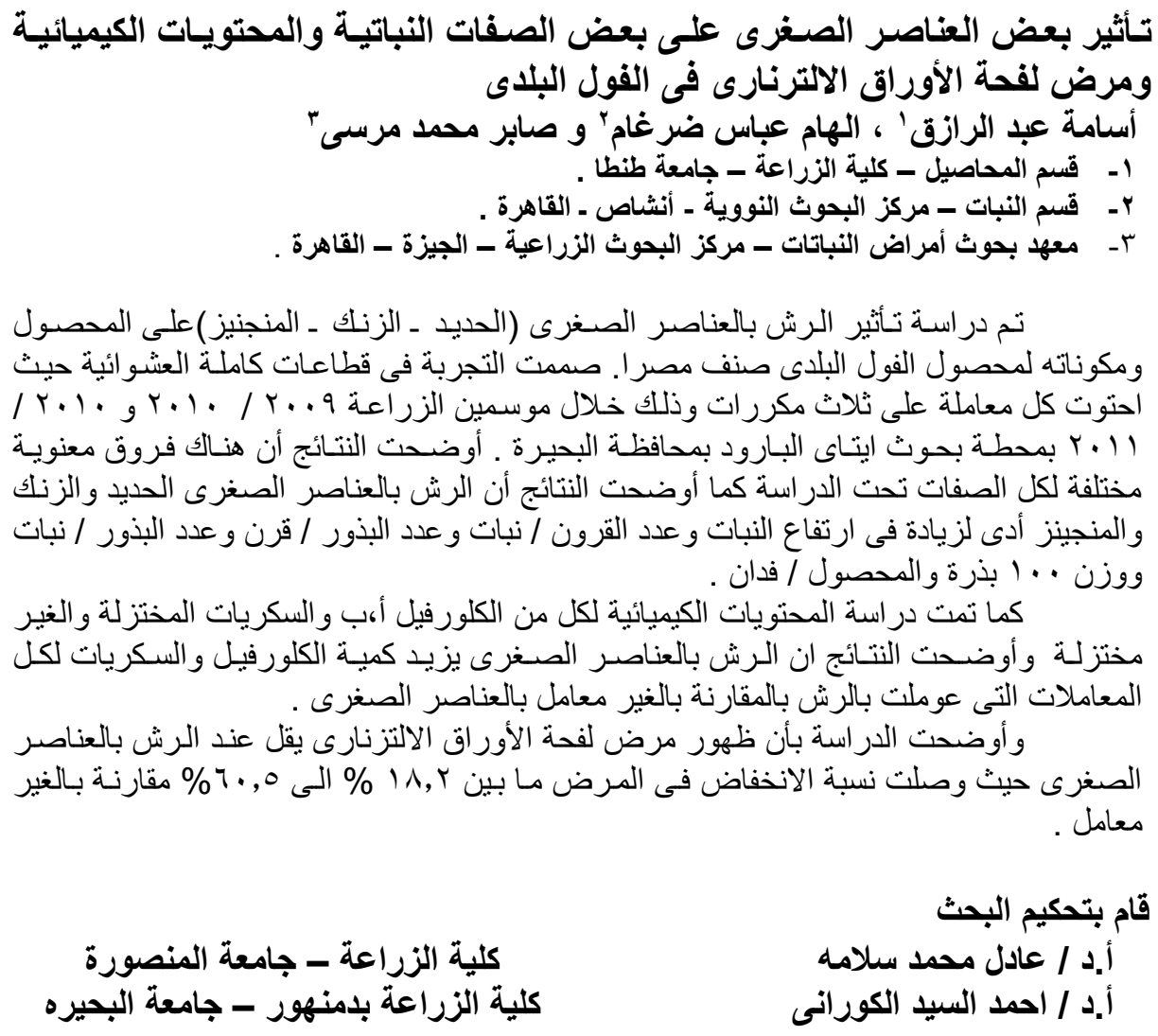


J. Plant Production, Mansoura Univ., Vol. 3 (11), Noveber, 2012

Disease severity \%

تلصق فى فيجر 1 